\title{
Induced spawning and early ontogeny in hatchery-reared catfish Zungaro jahu (Siluriformes: Pimelodidae)
}

\author{
Lorena B. Nogueira ${ }^{1}$, Pedro G. Azevedo ${ }^{1}$, Mônica R. Canelhas ${ }^{1}$, Alessandra G. Bedore², \\ João M. Lopes ${ }^{2}$ and Hugo P. Godinho ${ }^{1}$
}

\begin{abstract}
Hatchery-kept catfish jahus Zungaro jahu (Ihering, 1898) were induced to spawn with carp pituitary extract. The telolecithal eggs were round $(1.6 \pm 0.1 \mathrm{~mm}$ in diameter), demersal, free, and covered with a $0.4 \mathrm{~mm}$-thick jelly coat. The gonadosomatic index of 2.8 was comparable to that of other Pimelodidae. The number of eggs x g of ova ${ }^{-1}$ was $804 \pm 144$. Hatching occurred $14.5 \mathrm{~h}$ after fertilization, at a temperature of $27.3 \pm 0.4^{\circ} \mathrm{C}$. The newly-hatched embryos measured 3.9-4.3 mm of total length (TL). At $18 \mathrm{~h}$ posthatching (HPH; $5.3 \pm 0.1 \mathrm{~mm} \mathrm{TL}$ ), the retina was pigmented, the mouth opened and dorsoflexion of the notochord had initiated. At $36 \mathrm{HPH}(6.4 \pm 0.2 \mathrm{~mm} \mathrm{TL})$, fusiform chromatophores were vertically arranged in the primordial fin fold and the notochord was dorsoflexed. The yolk sac was almost exhausted by $48 \mathrm{HPH}(7.3 \pm 0.2 \mathrm{~mm} \mathrm{TL})$. At $128 \mathrm{HPH}(8.6 \pm 0.6 \mathrm{~mm}$ TL) the pectoral, dorsal, adipose, caudal, anal, and pelvic fins were readily observable whereas the primordial fin fold was no longer visible. At $224 \mathrm{HPH}$ $(16.6 \pm 2.5 \mathrm{~mm} \mathrm{TL})$, the metamorphosis was completed and the larvae had acquired the juvenile appearance.
\end{abstract}

Jaús Zungaro jahu (Ihering, 1898), mantidos em estação de piscicultura, foram induzidos à reprodução com extrato bruto de hipófise de carpa. Seus ovos são telolécitos, arredondados (1,6 $\pm 0,1 \mathrm{~mm}$ de diâmetro), demersais, livres e cobertos por uma capa gelatinosa com 0,4 mm de espessura. $O$ índice gonadossomático (peso da ova : peso total do peixe) de 2,8 foi semelhante ao de outros Pimelodidae. O número de ovos $\mathrm{x} g$ de ova $^{-1}$ foi $804 \pm 144$. A eclosão dos embriões ocorreu 14,5 h pós-fertilização à temperatura de 27,3 $\pm 0,4^{\circ} \mathrm{C}$. Os embriões recém-eclodidos apresentaram 3,9-4,3 mm de comprimento total (CT). Dezoito horas pós-eclosão (HPE) e 5,3 \pm $0,1 \mathrm{~mm} \mathrm{CT}$, a retina estava pigmentada, a boca aberta e a flexão da notocorda tinha se iniciado. Às $36 \mathrm{HPE}(6,4 \pm 0,2 \mathrm{~mm}$ CT), observaram-se cromatóforos fusiformes alinhados verticalmente na nadadeira primordial; a notocorda já se encontrava flexionada.

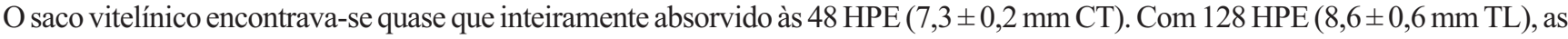
nadadeiras peitoral, dorsal, adiposa, caudal, anal e pélvica estavam formadas e a nadadeira primordial já havia sido reabsorvida. Com $224 \mathrm{HPE}(16,6 \pm 2,5 \mathrm{~mm} \mathrm{CT})$, a metamorfose se completou e as larvas se transformaram em juvenis.

Key words: Early ontogenesis, Growth, Morphological development, Neotropical catfish.

\section{Introduction}

The jahu Zungaro jahu (Ihering, 1898), one of the largest Neotropical freshwater fishes, has an estimated asymptotic fork length of $172 \mathrm{~cm}$ (Mateus \& Penha, 2007a) and weighs over $150 \mathrm{~kg}$ (Agostinho et al., 2003). It is a seasonal strategist, total spawner with high fecundity, and a migratory species that explores the seasonal pulse expansion of the aquatic environment (Winemiller, 1989; Mateus \& Penha, 2007a). The fry live mainly in the mouth of small tributaries while adults live in deeper areas of rivers (Agostinho et al., 2003; Alves et al., 2007).

Historically, this long-whiskered catfish was distributed along the La Plata River and its tributaries (Paraná, Paraguay, and Uruguay Rivers) in Argentina, Uruguay, Paraguay, and Brazil (Lundberg \& Littman, 2003; Agostinho et al., 2003;
Zaniboni Filho \& Schulz, 2003). Overfishing, hydroelectric dams, agriculture, mining, navigation and pollution have led to commercial and recreational catch reductions (Quirós, 1993; Agostinho et al., 2003; Zaniboni Filho \& Schulz, 2003). Primarily because of a lack of hydroelectric dams, jahu fisheries remain in the Paraguay and Cuiabá Rivers, in the northern Pantanal region, where they appear to be sustainable (Mateus \& Penha, 2007b). In contrast, in the southern Pantanal region, jahu stocks are showing signs of overexploitation (Resende, 2003). In the upper Paraná River basin jahu captures have drastically declined (Agostinho et al., 2003). As a consequence, jahu is officially listed as threatened in the Brazilian State of Minas Gerais (Godinho, 1998) and Paraná (Mikich \& Bérnils, 2004). Further south in the lower Paraná River, La Plata River, and Uruguay River, the jahu has practically disappeared from commercial catches (Quirós, 1993).

${ }^{1}$ Pontifícia Universidade Católica de Minas Gerais, Programa de Pós-Graduação em Zoologia de Vertebrados, 30535-610 Belo Horizonte, MG, Brazil.hgodinho@ufmg.br

${ }^{2}$ Estação Ambiental de Volta Grande, Companhia Energética de Minas Gerais, CEMIG GT, 38120-000 Conceição das Alagoas, MG, Brazil. 
Early life studies of fish are important to understand ontogeny and growth during this life period. Such studies in Neotropical freshwater migrants are difficult to conduct because they spawn in the river channel during floods, allowing embryos and larvae to disperse downstream into the expanded floodplains, impairing the ability to obtain complete wild developmental series. Also the multi-species assemblages that result from wild collections render the embryonic and larval taxonomic identifications problematic (Santos \& Godinho, 2002). However, hatchery-born migratory fish constitute an excellent alternative source for the study of their early life history. This approach has been successfully used (Nakatani et al., 2001; Marques, 2008; Marques et al., 2008) and we applied it to obtain novel data on the jahu early life history.

The objectives of this study were to provide data on reproductive characteristics of the jahu obtained through induced spawning and on the individual development from egg to larval metamorphosis.

\section{Material and Methods}

Fish maintenance. The broodstock comprising nine females and two males jahus, native to the Grande River, upper Paraná River basin, was held in an earthen pond at Volta Grande Hatchery Station, Minas Gerais, Brazil (2001'33"S $\left.48^{\circ} 13^{\prime} 10^{\prime \prime} \mathrm{W}\right)$. The pond had cement walls, $1,200 \mathrm{~m}^{2}$ in area, 1.5 $\mathrm{m}$ in depth, and was partially covered with a black plastic net to offer shade to the fish. The fish were ready to reproduce from November to January, corresponding to their natural reproductive season in the upper Paraná River basin (Agostinho et al., 2003). They were fed ad libitum on live juvenile fish (Prochilodus lineatus, Leporinus spp., Geophagus sp.) kept in the same pond. At the start of the experiment, the fish were transferred from the pond to individual $1.5 \mathrm{~m}^{3}$ aquaria. The water to the aquaria was supplied from Volta Grande Reservoir and had the following physical-chemical characteristics: temperature $\left({ }^{\circ} \mathrm{C}\right)=26.7 \pm$ $0.8, \mathrm{pH}=7.0 \pm 0.7$, conductivity $\left(\mu \mathrm{S} \times \mathrm{cm}^{-1}\right)=34.3 \pm 1.5$, and dissolved oxygen $\left(\mathrm{mg} \mathrm{x} \mathrm{cm}^{-1}\right)=7.0 \pm 0.3$.

Voucher specimens are maintained in the collection housed at the Universidade Católica de Minas Gerais, Belo Horizonte, MG, Brazil(MCNIOL 0001-0016).

Sperm handling. In the reproductive season of 2004-2005, the two males (male $\mathrm{A}=8.5 \mathrm{~kg}$ of body weight; male $\mathrm{B}=6.1$ $\mathrm{kg}$ of body weight) were used. According to Drumond (2008), jahus are injected with high doses of crude carp pituitary extract (CPE) to increase the small volume of sperm they usually release when kept in captivity. Thus, each male received two intramuscular injections containing respectively 0.5 and $5.0 \mathrm{mg}$ of CPE $\mathrm{x} \mathrm{kg}$ of body weight ${ }^{-1}$ with $14-16$ h of interval between them. However, only male B was able to release sperm when submitted to coelomic massage. Next, it was anesthetized with $0.1 \%$ menthol alcoholic solution, and had one of its testes surgically removed and ground with a mortar and pestle (Sato et al.,
1999). The celomic wall was sutured and the fish was left to recover but died some hours later.

The testicular sperm was then roughly separated from testis tissues using a fine net and cryopreserved following the protocol used for the catfish Pseudoplatystoma corruscans (Carolsfeld et al., 2003). Sperm motility rate (percent active sperm) was estimated following Bedore (1999). The sperm concentration (number of spermatozoa $\mathrm{x} \mathrm{ml}^{-1}$ ) of the freshly hand-stripped and of the testicular sperm were obtained using a Neubauer chamber after dilution in a $6 \%$ buffered formalin solution.

Assessment of ovarian maturation. Each female had a plastic catheter (internal diameter: $2.2 \mathrm{~mm}$, external diameter: $3.3 \mathrm{~mm}$ ) introduced into the ovarian lumen through the urogenital papilla. A sample of ovarian tissue containing oocytes was then withdrawn into an attached syringe. The samples were clarified in Serra's solution (Woynarovich \& Horváth, 1980) and examined on a stereomicroscope at $4 \mathrm{x}$ magnification. At least 100 yellowish vitellogenic oocytes with central nucleus were examined, indicating they had reached the maturation stage.

Induced spawning. Since jahus do not naturally spawn in captivity (Drumond, 2008), the animals were submitted to hormonal treatment to induce spawning. We used five females (10.0-15.6 kg of body weight) in the reproductive season of 2004-2005 and four (9.2-14.4 kg of body weight) in 2005-2006.

Induced spawning of the females was carried out with crude carp pituitary extract (CPE). It was injected in two doses (1.0 and $6.0 \mathrm{mg} \mathrm{x} \mathrm{kg} \mathrm{of} \mathrm{body} \mathrm{weight}^{-1}$, respectively) separated by an interval of $14 \mathrm{~h}$ to $16 \mathrm{~h}$ (Woynarovich \& Horváth, 1980), and given at the same time of those of the males. The ova (mass of released oocytes) were manually stripped and weighed (to the nearest $\mathrm{g}$ ). Ova samples, weighed to the nearest $\mathrm{mg}$, were fixed in $6 \%$ buffered formalin solution and later the oocytes were counted. Water temperature of the aquaria was hourly measured beginning with the second $\mathrm{CPE}$ injection and continuing until ovulation to estimate the degree-hours at spawning (sum of water temperature taken hourly within that period).

Although four out of five females spawned in the 20042005 reproductive season, the small amount of available fresh sperm at the moment of spawning limited fertilization to the ova of only one female. Fertilization was performed following the 'dry method' (Ihering \& Azevedo, 1936b; Woynarovich \& Horváth, 1980). In this procedure, $0.2 \mathrm{ml}$ of fresh sperm was gently mixed with aliquots of $40 \mathrm{~g}$ of ova. Then, $20 \mathrm{ml}$ of the aquarium water was added to activate the sperm for about 3 min. After that the eggs were rinsed with aquarium water and left $0.5 \mathrm{~h}$ in $1 \mathrm{~L}$ of the same water to hydrate.

In the 2005-2006 reproductive season, only one female out of four spawned. The procedures followed the same protocols used in 2004-2005, except the ova were fertilized using the cryopreserved sperm. The contents of 5 straws, thawed in a water bath at $40-50^{\circ} \mathrm{C}$ for $10 \mathrm{~s}$ were poured over the aliquots of $40 \mathrm{~g}$ of ova and gently mixed. About $20 \mathrm{ml}$ of $119 \mathrm{mM} \mathrm{NaHCO}_{3}$ were then added to the mixture for sperm 
activation and subsequent oocyte fertilization. Fertilization rate (percentage of viable embryos at the blastopore stage) was estimated under the microscope for approximately 300 eggs fixed in $6 \%$ buffered formalin solution.

The following sperm characteristics were obtained: volume, concentration, and rate of motility. Regarding the eggs, the following variables were registered: diameter of oocytes and eggs, ova weight, gonadosomatic index (= ova weight : body weight, $\%$ ), number of oocytes $\mathrm{x} g$ of ova ${ }^{-1}$, fertilization rate, degree-hours at spawning, and degree-hours at hatching.

Early life rearing and morphological development. In the reproductive seasons of 2004-2005 and 2005-2006, the fertilized eggs were placed in a funnel type, upwelling fiberglass incubator with $200 \mathrm{~L}$ of capacity. The water supply to the incubator came from the same source as that of the aquaria, thus sharing similar physical-chemical characteristics, and maintained at a flow of 4-5 L x min ${ }^{-1}$ (Dumont-Neto et al., 1997). The terminology used for the early ontogeny phases, i.e. cleavage egg (from oocyte fertilization to blastopore closure), embryo (from blastopore closure to hatching), free embryo (from hatching to yolk sac absorption) and larvae (from yolk sac absorption to metamorphosis), followed Balon (1975, 1999). Embryos and larvae were maintained in the same incubator throughout the rearing period that lasted 10 days.

The larvae were fed ad libitum beginning at 48 hours post-hatching with Artemia sp. nauplii and pond-produced whole plankton, 3-5 times $\mathrm{x}$ day $^{-1}$. The temperature of the incubation water was registered to estimate the degree-hours at hatching (i.e., the sum of temperatures at each hour from fertilization to hatching). Fish were exposed to the natural photoperiod and illuminated by the overhead fluorescent lights of the laboratory during the day.

The morphological development of eggs, embryos and larvae was examined fresh or after being fixed in $6 \%$ buffered formalin solution. Before fixation, embryos and larvae were anesthetized in $0.1 \%$ benzocaine solution. The egg diameter was measured to the nearest $0.1 \mathrm{~mm}$. We registered the type and timing of cleavage and blastopore (germ ring) closure; time of appearance of the optic and otic vesicles; presence of somites; yolk sac absorption; presence of the Kupffer's vesicle; and time of hatching.

During the free embryo phase, the following characteristics were registered: total length of the free embryo during development, fate of the primordial fin fold, pigmentation of body, retina and primordial fin fold, and notochord flexion, presence of miotomes, and timing of external structure appearances. During the larval development the following characteristics were registered: end of yolk sac exhaustion, appearance of definitive fins and their rays, and completion of metamorphosis.

All measurements were made to the nearest $0.1 \mathrm{~mm}$ from printed images captured on a digital camera coupled to the stereomicroscope. No correction was made for formalin larval shrinkage which we estimated at approximately $2.3 \%$ in the free embryo phase.

\section{Results}

At the time of the crude carp pituitary extract injections, the female genital papilla was pale but gradually turned reddish and swollen near to spawning. During hormonal treatment, the females remained quiet in the bottom of the aquarium, except at the time of ovulation when they swam around. Five of the nine females spawned following the hypophysation treatment. No fish died due to the treatment.

Gametes. The hand stripped sperm was clear and very fluid. Sperm volume, sperm concentration, and sperm motility rate are shown in Table 1. The oocytes were released in a single batch. The diameter of oocytes and eggs, width of the perivitelline space, ova weight, gonadosomatic index, number of eggs x $\mathrm{g}$ of $\mathrm{ova}^{-1}$, and fertilization rate are shown in Table 1. The oocytes were telolecithal, opaque, spherical, light yellow, demersal and free, and non-adhesive. Each oocyte was covered by a transparent, $0.4 \mathrm{~mm}$ thick jelly coat (Fig. 1a).

Morphological development. The early life ontogeny of the jahu, from fertilization up to $224 \mathrm{~h}$ post-hatching $(\mathrm{HPH})$ when metamorphosis was reached, comprised the following phases: cleavage eggs, embryo, free embryo, and larva.

Cleavage eggs. Egg hydration started almost immediately following fertilization. Fifteen min post-fertilization (PF), the cortical cytoplasm began to move towards the animal pole to form the blastodisc. At $1.5 \mathrm{~h}$ post-fertilization (HPF), the eggs reached $2.4 \pm 0.1 \mathrm{~mm}$ in diameter and $7.6 \pm 1.0 \mathrm{~mm}^{3}$ in volume due

Table 1. Data (mean \pm SD, where applicable) from induced reproduction of jahu Zungaro jahu. $\mathrm{N}=$ number of individuals analyzed.

\begin{tabular}{|c|c|}
\hline Parameter & Value \\
\hline \multicolumn{2}{|l|}{ Male } \\
\hline Body weight (kg) & 6.1 \\
\hline \multicolumn{2}{|l|}{ Sperm volume $(\mathrm{ml})$} \\
\hline Hand-stripped & 1.9 \\
\hline Testicular & 8.3 \\
\hline \multicolumn{2}{|l|}{ Sperm concentration (spermatozoa x $10^{9} \mathrm{ml}^{-1}$ ) } \\
\hline Hand-stripped & 12.6 \\
\hline Testicular & 62.7 \\
\hline \multicolumn{2}{|l|}{ Sperm motility rate $(\%)$} \\
\hline Fresh testicular & $>90$ \\
\hline Cryopreserved testicular & 70 \\
\hline \multicolumn{2}{|l|}{ Females } \\
\hline Body weight (kg) & $10.0-15.6$ \\
\hline Spawning efficiency $(\%)$ & 55.5 \\
\hline Oocyte diameter, $\mathrm{mm}$ & $1.6 \pm 0.1(20)$ \\
\hline Egg diameter (after hydration), mm & $2.4 \pm 0.1(40)$ \\
\hline Width of perivitelline space, $\mathrm{mm}$ & $0.5 \pm 0.05(48)$ \\
\hline Ova weight, $g$ ( $\mathrm{n}$ of females) & $352(3)$ \\
\hline $\begin{array}{l}\text { Gonadosomatic index (ova weight : body weight, \%), } \\
\text { (n of females) }\end{array}$ & $2.8(3)$ \\
\hline Number of eggs $x g$ of ova $^{-1}$ ( $n$ of females) & $804 \pm 144(3)$ \\
\hline \multicolumn{2}{|l|}{ Fertilization rate $(\%)$} \\
\hline Fresh sperm & 92 \\
\hline Cryopreserved testicular sperm & 78 \\
\hline Degree-hours at spawning & $220-230$ \\
\hline Degree-hours at hatching & 410 \\
\hline
\end{tabular}


to the formation of a large perivitelline space $(0.5 \pm 0.05$ in width). That size was maintained throughout the embryonic phase.

Cleavage was discoidal meroblastic. The first divisions were synchronous and the resulting blastomeres were of similar sizes. By $45 \mathrm{~min}$ PF, the first two blastomeres were seen. They resulted from a meridional cleavage plane which divided the blastodisc into equal halves (Fig. 1b, c).

At $50 \mathrm{~min} \mathrm{PF}$, four blastomeres resulted from a second cleavage plane that was meridional and perpendicular to the first one (Fig. 1d). Soon after, eight blastomeres were formed (Fig. 1e).

Between $1 \mathrm{~h}$ and $1 \mathrm{~h} 30 \mathrm{~min} \mathrm{PF}$, meridional cleavage planes gave rise to 16 (Fig. 1f) and 32 blastomeres (Fig. 1g) respectively, apparently still of the same size. The latter occupied a curved area over the yolk sac.

At $1 \mathrm{~h} 40 \mathrm{~min}$ PF, 64 blastomeres were present and cleavage advanced in a non-synchronous pattern with the occurrence of latitudinal planes resulting in two layers of blastomeres.

At $2 \mathrm{~h} 10 \mathrm{~min}$ PF, a morula was present (Fig. 1h) which became flattened by 4 h PF. By 4 h 40 min PF, the thickened marginal embryo ring representing the outer limit of the blastoderm during the epiboly movement covered $50 \%$ of the yolk sphere (Fig. 1i).

Blastopore (germ ring) was almost closed by $6 \mathrm{~h} 30 \mathrm{~min} P F$ (Fig. 1j) and completely closed at $7 \mathrm{~h} 30 \mathrm{~min}$ PF (Fig. 1k).

Embryo. Following blastopore closure the embryo acquired an elongated shape. The vegetal pole (yolk) was completely surrounded by the blastoderm forming the yolk sac.

By $10 \mathrm{~h} 30 \mathrm{~min}$ PF, the optic cups could be seen and soon they developed into optic vesicles. The embryo also showed the otic vesicles (whose ossicles were not observed) in the cephalic region, and a Kupffer's vesicle in the caudal region. The embryo had 13 somites (Fig. 11).

At $13 \mathrm{~h} 30 \mathrm{~min}$ PF, the tail had separated from the yolk sac and had started beating (Fig. $1 \mathrm{~m}$ ). Hatching started at approximately $14 \mathrm{~h} 30 \mathrm{~min} \mathrm{PF}$, and in less than $6 \mathrm{~h}$ all embryos had hatched. The Kupffer's vesicle was no longer visible at this time.

Free embryo. The free embryo (eleuteroembryo) phase extended from hatching to $48 \mathrm{~h}$ post-hatching $(\mathrm{HPH})$ when exogenous feeding started. External morphological features of the free embryos during development are shown in Fig. 1n and Fig. 2a, b, c.

The recently hatched free embryo $(0-6 \mathrm{HPH}, 3.9 \pm 0.0-$ $4.3 \pm 0.2 \mathrm{~mm}$ TL) had an almost transparent body. The head and anterior part of the body rested over the prominent yolk sac. The non-pigmented primordial fin fold extended from the dorsal limit of the head over the entire body except the yolk sac. Only a few dendritic chromatophores were observed on the rostral portion of the head and body. The retina was not pigmented and the mouth closed. Maxillary and mental barbel buds were present. A straight gut ended in the closed anus situated in the ventral border of the mid portion of the body. The notochord was slightly flexed (Fig 1n).

At 8-9 HPH (4.5 $\pm 0.3 \mathrm{~mm} \mathrm{TL})$, pigmentation initially appeared at the center of the retina of the free embryo, and then spread outward to the periphery.
The mouth was apparently opened as early as $15 \mathrm{HPH}$ $(5.0 \pm 0.2 \mathrm{~mm}$ TL $)$. By $18 \mathrm{HPH}(5.3 \pm 0.1 \mathrm{~mm} \mathrm{TL})$, the retina was already pigmented and chromatophores, mainly fusiform-shaped, appeared vertically aligned in the primordial fin fold (Fig. 2a).

At $24 \mathrm{HPH}(5.9 \pm 0.2 \mathrm{~mm}$ TL$)$, the pigmented primordial fin fold became protruded in the areas of the future dorsal, adipose and anal fins; the dorsal end of the caudal fin fold assumed an elongated shape (Fig. 2b).

By $36 \mathrm{HPH}(6.4 \pm 0.2 \mathrm{~mm} \mathrm{TL})$, the primordial fin fold was heavily pigmented, except in the caudal area where pigmentation remained absent. The pectoral fin buds were the first to appear. Associated with the appearance of caudal ray rudiments, the caudal segment of the notochord achieved complete flexion when it reached an angle of $30^{\circ}$ with the notochord axis (Fig. 2c).

At $48 \mathrm{HPH}(7.3 \pm 0.2 \mathrm{~mm} \mathrm{TL})$, the yolk sac was almost exhausted; thereafter the number of miotomes was constant $(\mathrm{n}=52.9 \pm 1.3$, being $21.1 \pm 1.0$ preanal and $31.8 \pm 1.1$ postanal).

Larva. The larval development was accomplished in the period between $48 \mathrm{HPH}$ and $224 \mathrm{HPH}$. External larval traits during development are shown in Figs. 2d, e and f.

At the beginning of the larval development, a residual yolk sac was still observable. At $80 \mathrm{HPH}(7.7 \pm 0.4 \mathrm{~mm} \mathrm{TL})$, the primordial fin fold was completely absorbed except at the preanal region; the rays of the caudal fin were visible (number of rays $=19)$.

At $128 \mathrm{HPH}(8.6 \pm 0.6 \mathrm{~mm} \mathrm{TL})$, the preanal primordial fin fold was no longer present. The pectoral, dorsal, and anal fin rays were visible. The dorsal and anal fins showed, respectively, 7 and $8-13$ rays (Fig. 2d); rays of the pectoral fins were not counted.

At $152 \mathrm{HPH}(10.2 \pm 0.9 \mathrm{~mm} \mathrm{TL})$, the maxillary barbels had grown caudally and surpassed the level of the anus (Fig. 2e). The pelvic fin rays appeared close to metamorphosis (203 $\mathrm{HPH}, 14.4 \pm 1.9 \mathrm{~mm} \mathrm{TL})$.

By the end of the larval development, the caudal fin had assumed the forked shape of the adult. At 224 HPH (16.6 \pm 2.5 mm TL) most fish resembled juveniles (Fig. 2f).

\section{Discussion}

Brazilian iteroparous, oviparous, freshwater teleosts that only spawn in large rivers present large body size, spawning migration, shorter reproductive season, single (total) spawning, no parental care, free eggs, and fast embryogenesis (Godinho et al., 2010). Our data on total spawning, free eggs, and fast embryogenesis associated to other characteristics indicated elsewhere (Agostinho et al., 2003; Alves et al., 2007) categorize the jahu in the group of migratory fishes.

In general, the urogenital papilla redness is an external characteristic used to select females especially, but also males, for induced spawning (Sato et al., 2003b). However, our selected females and males presented pale and flat papilla prior to the hormonal treatment. They turned pale reddish and swollen only near spawning.

When kept in treatment tanks certain migratory females 

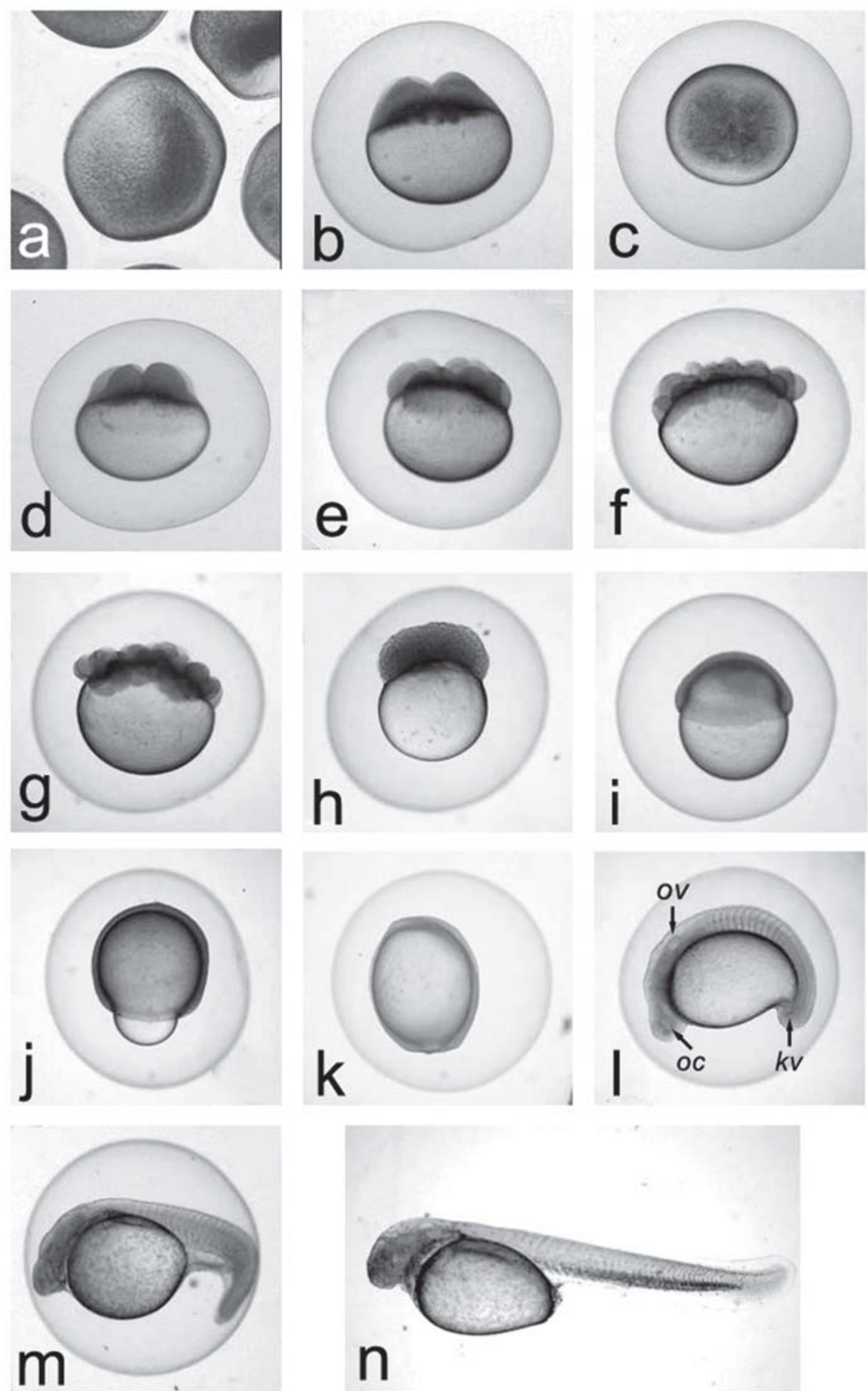

Fig. 1. Steromicroscopic images of fresh oocytes (a; $1.6 \mathrm{~mm}$ in diameter), eggs (b-k; 2.4 mm in diameter), embryos (l-m; 2.4 $\mathrm{mm}$ in diameter), and free embryo (1-n; $4.3 \mathrm{~mm}$ TL) of jahu in hatchery conditions. a) recently spawned oocyte covered by the jelly coat (arrow); b) egg showing a large perivitelline space and two blastomeres of same size (45 min post fertilization, PF); c) dorsal view of egg seen in $\mathbf{b} ; \mathbf{d})$ egg with four blastomeres of same size (50 min PF); e) egg with eight blastomeres of same size (50 min PF); f) egg with sixteen blastomeres of same size (1 h $15 \mathrm{~min} \mathrm{PF);} \mathrm{g)} \mathrm{egg} \mathrm{with} \mathrm{thirty-two} \mathrm{blastomeres} \mathrm{of} \mathrm{same} \mathrm{size} \mathrm{(1} \mathrm{h}$ $20 \mathrm{~min} \mathrm{PF}$ ); h) morula stage (2 h $10 \mathrm{~min} \mathrm{PF);} \mathrm{i)} \mathrm{half} \mathrm{of} \mathrm{the} \mathrm{yolk} \mathrm{sphere} \mathrm{(circa} \mathrm{50 \%} \mathrm{epiboly)} \mathrm{was} \mathrm{covered} \mathrm{with} \mathrm{the} \mathrm{blastoderm} \mathrm{(4}$ h 50 min PF); j) formation of the yolk plug circa $90 \%$ epiboly ( 6 h 30 min PF); k) end of epiboly with closure of embryo ring (blastopore) (7 h 30 min PF); l) embryo exhibiting optic calyx (OC), otic vesicle (OV), Kupffer's vesicle (KV), and 13 somites (10 h $30 \mathrm{~min}$ ); m) embryo within egg envelop exhibiting free, beating tail (13 h $30 \mathrm{~min}$ PF); n) free embryo, the almost transparent body is involved by the primordial fin fold; head and anterior part of body over the yolk sac; non-pigmented retina; mouth is closed; notochord slightly flexed; $39.1 \pm 2.0$ miotomes (circa $6 \mathrm{~h}$ post hatching). 
exhibit a vigorously swim behavior which may be used as a clue of imminent ovulation, for example Brycon orthotaenia and Prochilodus costatus (Sato et al., 2003b). Although no specific behavior has been assigned to Siluriformes (Sato et al., 2003b), we recognized discrete swimming movements of the female jahus just prior to ovulation.

The protocol largely used in Brazil to induce spawning of migratory fishes, named hypophysation (Ihering \& Azevedo, 1936b), was applied to jahu with an efficiency similar to that obtained by Zaniboni Filho \& Barbosa (1996) in the same species. It was also within the $50-59 \%$ range of efficiency registered in other Neotropical Siluriformes: Conorhynchus conirostris (Sato, 1999), Pseudopimelodus corruscans (Sato et al., 1997; Sato et al., 2003b), and Pseudoplatystoma sp. (Dabrowski et al., 2008). However, higher efficiencies (60-70\%) have been registered in other catfishes, such as Rhamdia quelen and Pimelodus maculatus (Sato, 1999), and even higher (>70\%) in Rhinelepis aspera (Sato et al., 1998) and Pseudoplatystoma fasciatum (Padilha Peréz et al., 1991; Leonardo et al., 2004; Romagosa et al., 2005; Nuñez et al., 2008).

Captive Brazilian migratory males release sperm without hormonal treatment during the reproductive season. In most species, a significant increase in sperm volume matched with a reduction in sperm concentration is observed when they are hormonally treated (review in Viveiros \& Godinho, 2009). Our male jahus did not reach fully maturation, as indicated by the low sperm volume released after CPE treatment and the pale aspect of the surgically removed testis. Apparently this is not a unique condition of jahu (Drumond, 2008) since poor sperm production has also been observed in other Brazilian fishes kept in hatchery: Pimelodus maculatus (Sato et al., 1999), Leporinus macrocephalus (Ribeiro \& Godinho, 2003). Drumond (2008) was able to extract $15 \mathrm{~mL}$ of sperm from a jahu, following the treatment protocol of Zaniboni Filho \& Barbosa (1996) which consisted of a priming injection of $0.25 \mathrm{mg}$ of CPE $\mathrm{x} \mathrm{kg}$ of body weight $^{-1}, 1$ or 3 days previously to the regular injections.

Both volume and concentration of testicular sperm of jahu were higher than that obtained by massage of the coelomic wall. The rate of motility of the frozen testicular sperm reached almost $80 \%$ of that of fresh testicular sperm. Thus, the testicular sperm responded well to the cryopreservation protocol previously applied to the catfish Pseudomimelodus corruscans and other species (Carolsfeld et al., 2003; Viveiros \& Godinho, 2009). The frozen sperm cells were in good functional condition considering their high motility and fertilization rates. The same protocol has been used with equal success for the sperm of jahu collected by coelomic massage (personal observation). Considering the results of the present work, a sperm gene bank using this
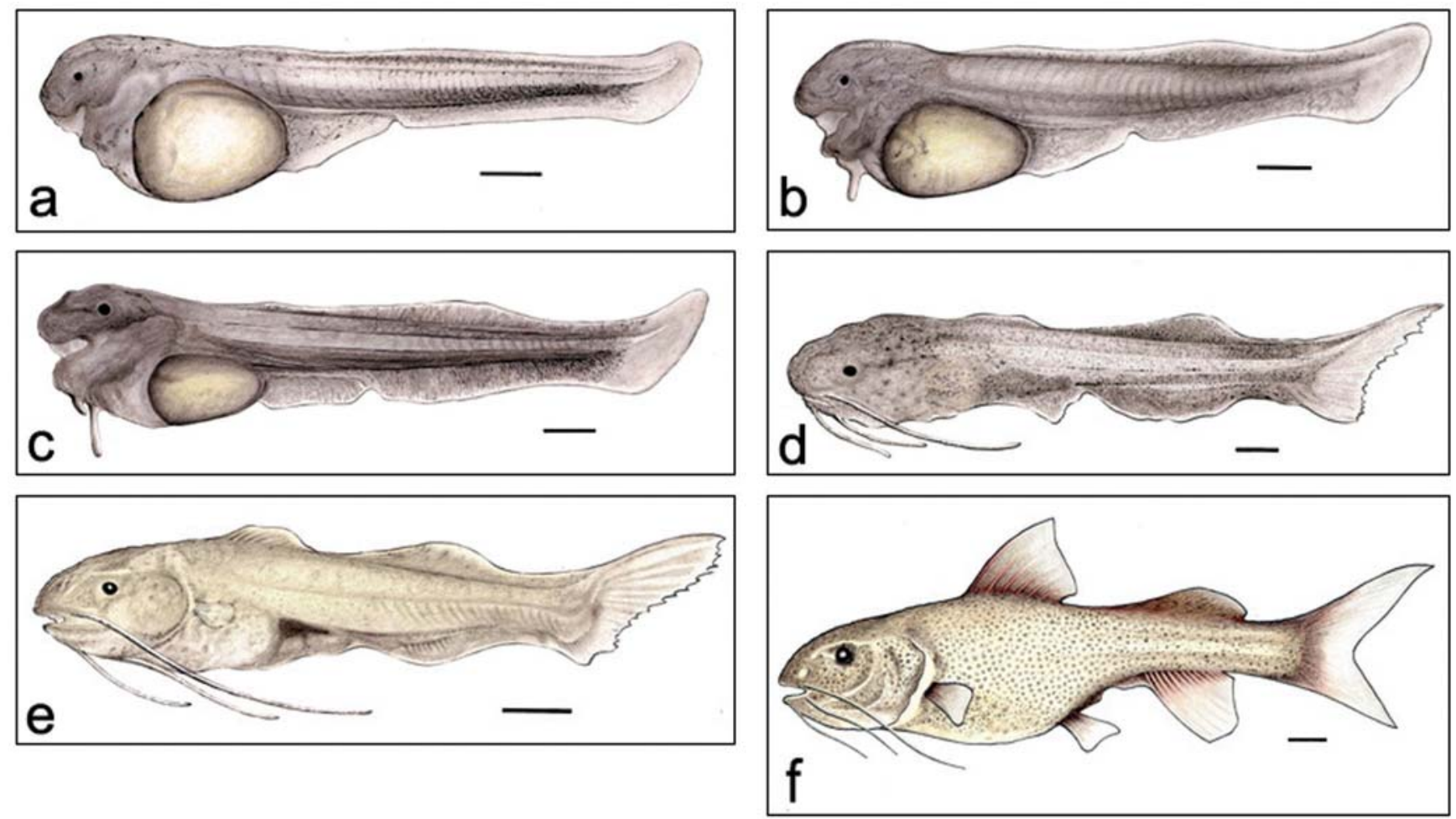

Fig. 2. Drawings of free embryos (a-c), larvae (d-e) and juvenile (f) of hatchery - raised jahus. a) free embryo (18 h post hachting, $\mathrm{HPH} ; 5.3 \mathrm{~mm} \mathrm{TL}$ ) presenting pigmented retina, opened mouth and slightly pigmented primordial fin fold; bar $=0.5 \mathrm{~mm}$. b) free embryo (24 HPH, $5.9 \mathrm{~mm}$ TL) showing developing mental barbel and pigmented primordial fin fold except in the caudal portion; bar=0.5 mm. c) free embryo ( $36 \mathrm{HPH}, 6.4 \mathrm{~mm} \mathrm{TL}$ ) showing growing mental barbels, primordial fin fold chromatophores vertically arranged, yolk sac well reduced in size, outline of adipose fin was present, dorsoflexion of notochord was completed; bar $=0.5 \mathrm{~mm}$. d) $1 \mathrm{arva}(128 \mathrm{HPH}$, $8.6 \mathrm{~mm}$ TL) showing developing maxillary and mental barbels, outline of pelvic, and anal fins; bar $=0.5 \mathrm{~mm} . \mathbf{e})$ larva $(152 \mathrm{HPH}, 14.4 \mathrm{~mm}$ $\mathrm{TL})$ in which pectoral, dorsal and caudal fins are seen; bar =1.0 mm. f) juvenile jahu (224 HPH, $16.6 \mathrm{~mm} \mathrm{TL})$; bar $=1.0 \mathrm{~mm}$. 
cryopreservation technology could be used to increase genetic diversity on the basis proposed by Carolsfeld et al. (2003) in programs for enhancement, mitigation or conservation breeding.

Oocyte viability refers to the time interval during which fertilization of ovulated oocytes remains possible once they have been emitted by the female, or exposed soon after stripping to water or various solutions (Legendre et al., 1996). The loss of oocyte viability is one of the limiting factors in induced reproduction, and delays in collecting ovulated oocytes can cause a significant loss in fertilization (Legendre et al., 2000; Rizzo et al., 2002; Phelps et al., 2007). Since ovulation response to hormonal treatment is temperature influenced (Phelps et al., 2007), degree-hours at spawning gives a practical indication of the time for stripping females. At the same water temperatures, degree-hours at spawning tend to be similar among species of a same taxonomic group, for example: Salminus, Brycon, Leporinus, Schizodon, Prochilodus (Sato et al., 2003b), and Pimelodidae (Baldisserotto \& Neto, 2005; Caneppele et al., 2009). This was the case of jahu whose degree-hours at spawning of 220-230 were close to that of other pimelodids, such as Pimelodus, Conorhynchus, Rhamdia, Lophiosilurus, Pseudopimelodus (Sato et al., 2003b), Pseudoplatystoma (Sato et al., 2003b; Nuñez et al., 2008), and Steindachneridion parahybae (Caneppele et al., 2009). The identification of spawning behavior and the determination of the degree-hours at spawning of jahu might help to obtain higher rates of fertilization by collecting oocytes at the propitious ovulation time.

The size of the jahu recently spawned oocyte $(1.6 \mathrm{~mm}$ in diameter) is among the largest in migratory Siluriformes. In this group of fishes, oocyte diameter varies from small, such as 1.0$1.2 \mathrm{~mm}$ in Pseudoplatystoma corruscans and Pimelodus maculatus to large, such as $1.3-1.6 \mathrm{~mm}$ in $C$. conirostris, $R$. quelen and $R$. aspera (Sato et al., 2003a). The gonadosomatic index of migratory Siluriformes does not surpass the $7 \%$ registered in $R$. aspera. In contrast, in some Characiformes (such as Prochilodus argenteus and P. costatus) it reaches over $22 \%$ (Sato et al., 2003a). Thus, catfishes characteristically have low gonadosomatic index and the $2.8 \%$ (represented here by the ova weight : body weight relationship) of the jahu was among the lowest registered in this group.

The number of eggs $\mathrm{x}$ g of ova ${ }^{-1}$ of the jahu was low and comparable, among migratory Siluriformes, only to that of Rinelepis aspera (718 \pm 31 , Sato et al., 2003a). Recently, Caneppele et al. (2009) registered the still smaller number of 324 eggs $x$ g of ova-1 in the catfish $S$. parahybae. The volume of jahu egg $\left(7.2 \mathrm{~mm}^{3}\right)$, mainly represented by the enlarged perivitelline space, increased 3.4 times over that of the recently spawned oocyte.

Jelly coat is commonly present in eggs of Siluriformes (Legendre et al., 1996; Nakatani et al., 2001; Rizzo et al., 2002; Amorim et al., 2009) including jahu. It is also present in other groups of fishes, such as Perciformes, Cypriniformes, and Cyprinodontiformes (Riehl \& Patzner, 1998), the characid Astyanax bimaculatus (Rizzo et al., 2002), and sturgeons (Psenicka et al., 2010). Its role in the ecophysiology of fish eggs is not well established. Apparently, no relationship between jelly coat and egg adhesiveness has been found since it is present in fishes bearing adhesive and non-adhesive eggs (Rizzo et al., 2002). In the sturgeon Acipenser baerii, the jelly coat covers the entire egg and acts like a stopper over the micropyles and is released in the freshwater within one min (Psenicka et al., 2010).

The discoidal meroblastic cleavage of the jahu telolecithal egg is a characteristic found in teleosts (Cardoso et al., 1995; Meijide \& Guerrero, 2000; Ninhaus-Silveira et al., 2006; Marques, 2008). In jahu, the blastomeres become smaller as their number increase (Marques, 2008), a condition which is also observed in other teleosts: Prochilodus lineatus (NinhausSilveira et al., 2006), Brycon cephalus (Alexandre et al., 2009).

Blastopore (=germ ring) closure indicates the beginning of the embryo phase. In jahu it lasted about $51 \%$ of the time of embryo formation. In other Siluriformes, blastopore closure takes a considerable lesser time (all the following percentages presented herein were calculated using the data presented in the respective paper) : $28.6 \%$ in Pimelodus maculatus (Luz et al., 2001), 31.4\% (Amorim et al., 2009) or 28.8\% (RodriguesGaldino et al., 2009) in R. quelen, 31.6\% (Cardoso et al., 1995) or 29.4\% (Landines et al., 2003) in Pseudoplatystoma corruscans. Teleosts bearing external fertilization can be induced to parthenogenesis in which egg activation takes place without sperm participation (Komen \& Thorgaard, 2007). However, this process does not reach the blastopore closure (Perini et al., 2009) and all parthenogenetic eggs are dead at this stage. Thus blastopore closure is an appropriate moment to estimate fertilization rates (Woynarovich \& Horváth, 1980; Godinho, 2007) since dead eggs can be easily excluded from the evaluations.

During embryo development, the transient ciliated fluidfilled Kupffer's vesicle appeared by $10.5 \mathrm{HPF}$ and lasted less than $3 \mathrm{~h}$, when the jahu embryo presented 13 somites. The appearance time of Kupffer's vesicle in the jahu corresponded to that of the catfish $R$. quelen raised at $27^{\circ} \mathrm{C}$ (Rodrigues-Galdino et al., 2009) and closely followed that of Pseudoplatystoma corruscans (Cardoso et al., 1995; Marques et al., 2008). In jahu embryos raised in slightly higher water temperature $\left(29.4^{\circ} \mathrm{C}\right)$, the Kupffer's vesicle appears at 9 HPF (Marques, 2008). It has been shown that the epithelial cilia of the Kupffer's vesicle are an essential component of a conserved mechanism for the establishment of left-right asymmetry in the gut, heart and brain in zebrafish (Essner et al., 2005; Aamar \& Dawid, 2010).

In jahu embryo maintained at $29.4^{\circ} \mathrm{C}$, tail beating and hatching occur, respectively, at $11 \mathrm{HPF}$ and $13 \mathrm{HPF}$ (Marques, 2008) which are slightly earlier than in our jahu embryos. Hatching is not a fixed threshold, but is triggered by environmental cues (e.g. low oxygen tension, light intensity, release of hatching enzymes as a cue to adjacent eggs) at different times during the embryo development (Balon, 1999). To allow comparisons among species on the response time at hatching under different temperatures, we used degree-hours at hatching. The degree-hours at hatching vary less than $10 \%$ within the same species: $382-395$ in jahu (Marques, 2008; present work), 450-489 in P. corruscans (Cardoso et al., 1995; Sato et al., 1997; Landines et al., 2003; Sato et al., 
2003b; Marques et al., 2008), and 1022-1104 in R. aspera (Sato et al., 2003b; Perini et al., 2009). Thus, hatching time in hatchery conditions may be estimated fairly accurately in these catfishes through degree-hours.

As for a large number of teleost species (Nakatani et al., 2001), most functional systems of the newly-hatched jahus were still under differentiation. The primordial fin fold is a characteristic present in the early development of most teleosts (Kendall et al., 1984). Similarly, the primordial fin fold of the jahu is formed in the embryo prior to hatching. After having some of its areas differentiated into unpaired fins, the remaining parts were absorbed. The timing of primordial fin fold growth, differentiation and disappearance varies greatly among different fish groups (van Snik et al., 1997). As regarding the jahu, residual primordial fin fold was not registered beyond $80 \mathrm{HPH}$ and $7.7 \pm 0.4 \mathrm{~mm}$ TL, except for its preanal segment which persisted up to $128 \mathrm{HPH}(8.6 \pm 0.6 \mathrm{~mm} \mathrm{TL})$.

The function of the primordial fin fold is still speculative and van Snik et al. (1997) raised two possibilities: first, being adapted for swimming in laminar water flows characterized by smooth water motion; second, in respiration by enlarging the surface to volume ratio of the early fish. It has also been suggested that the persistence of the preanal fin fold for a relatively longer time is related to reducing the drag forces on the body during the early life stages (Gisbert, 1999).

Notochord flexion is associated with the development of the caudal peduncle and the increase in swimming efficiency. It is responsible for the transition from an anguilliform to a subcarangiform swimming mode, being a valuable strategy in fishes to reduce the high cost of larval locomotion (Gisbert et al., 2002). Although there are no available data on the early swimming behavior of jahus, the notochord flexion, as a hypothesis, should also result in an improvement in its swimming capability and feeding as well.

Pigmentation is an important embryonic and larval characteristic which may be useful in species identification (Meijide \& Guerrero, 2000). Chromatophores had been identified as early as $10 \mathrm{~h} \mathrm{PF}$ in the embryos of jahus. The recently hatched embryo was almost completely free of pigmentation but soon chromatophores became abundant in different areas of its body. The two types of chromatophores, dendritic and punctate, identified in Neotropical fish (Nakatani et al., 2001), were present in the early ontogeny of the jahu. Another chromatophore type, fusiform in shape, appeared very early in ontogeny and characteristically filled the primordial fin fold. Pigmentation patterns also provide insights into the ecology and behaviour of early phenotypes. For example, the vertically arranged chromatophores of the primordial fin fold are likely to be related to larval camouflage (Hilsdorf et al., 2002). The lack of chromatophores in the area of the future caudal fin would help to reduce or eliminate predation, as predators often focus on the tail (Baras, 1999).

The sequence of fin formation in jahus: pectoral, adipose, caudal, dorsal, pelvic, and anal was not followed by a same sequence of fin ray acquisition. Although the pectoral fins were present in the early larvae, their rays appeared later in development.

Retinal pigmentation and mouth opening of jahus were completed almost simultaneously $(<18 \mathrm{HPH})$ since they were closely related to first exogenous feeding. Yolk sac absorption for Neotropical fishes lasts from 2.5 days in R. quelen (Ihering \& Azevedo, 1936a) to 8.8 days in Hoplias malabaricus (Matkovic \& Pisanó, 1989). The process of yolk sac consumption in jahu indicated a relatively quick exhaustion.

It is well known that water temperature influences development and growth especially during the rapidly growing larval and juvenile stages (Kamler, 1992, Rodrigues-Galdino et al., 2009). In the upper Paraná River, fish reproduction is most intense when water temperatures are higher (Baumgartner et al., 2008). In rivers where jahus are still present (such as the Prata River, a tributary of the Paranaíba River, upper Paraná River basin), the water temperature may reach up to $30^{\circ} \mathrm{C}$ ( Instituto Mineiro de Gestão das Águas, 2008). This might be at least $3^{\circ} \mathrm{C}$ higher than the water temperature in which our jahus were raised. In such a condition, early growth in the natural environment could be faster than in the hatchery. Thus eventual differences in growth should be taken into consideration when evaluating early ontogeny of jahus collected in the wild as compared to those obtained in hatchery.

\section{Acknowledgements}

We thank CEMIG GT, the Energy Company of the State of Minas Gerais, Brazil, for providing financial support (Project CEMIG P\&D 208) and allowing us to use the facilities of the Volta Grande Hatchery Station. We would also like to thank Paulo H. Leite de Souza for his skilful drawings.

\section{Literature Cited}

Aamar, E. \& I. B. Dawid. 2010. Sox17 and chordin are required for formation of Kupffer's vesicle and left-right asymmetry determination in zebrafish. Developmental Dynamics, 239: 2980-2988.

Agostinho, A. A., L. C. Gomes, H. I. Suzuki \& H. F. Júlio Jr. 2003. Migratory fishes of the Upper Paraná River Basin, Brazil. Pp. 23-98. In: J. Carolsfeld, B. Harvey, C. Ross \& A. Baer (Eds.). Migratory fishes of South America: biology, fisheries and conservation status. Victoria, World Fisheries Trust, the World Bank and the International Development Research Centre, 372p.

Alexandre, J. S., A. Ninhaus-Silveira, R. Veríssimo-Silveira, H. Buzollo, J. A. Senhorini \& M. P. Chaguri. 2009. Structural analysis of the embryonic development in Brycon cephalus (Günther, 1869). Zygote, 18: 173-183.

Alves, C. B. M., L. G. M. Silva \& A. L. Godinho. 2007. Radiotelemetry of a female jaú, Zungaro jahu (Ihering, 1898) (Siluriformes: Pimelodidae), passed upstream of Funil Dam, rio Grande, Brazil. Neotropical Ichthyology, 5: 229-232.

Amorim, M. P., B. V. C. Gomes, Y. S. Martins, Y. Sato, E. Rizzo \& N. Bazzoli. 2009. Early development of the silver catfish Rhamdia quelen (Quoy \& Gaimard, 1829) (Pisces: Heptapteridae) from the São Francisco River Basin, Brazil. Aquaculture Research, 40: 172-180. 
Baldisserotto, B. \& J. R. Neto. 2005. Jundiá (Rhamdia sp.). Pp. 303325. In: B. Baldisserotto. \& L. C. Gomes (Eds.). Espécies nativas para piscicultura no Brasil. Santa Maria, Editora UFSM, 470p.

Balon, E. K. 1975. Reproductive guilds of fishes: a proposal and definition. Journal of the Fisheries Research Board of Canada, 32: 821-864.

Balon, E. K. 1999. Alternative ways to become a juvenile or a definitive phenotype (and on some persisting linguistic offenses). Environmental Biology of Fishes, 56: 17-38.

Baras, E. 1999. Sibling cannibalism among juvenile vundu under controlled conditions. I. Cannibalistic behaviour, prey selection and prey size selectivity. Journal of Fish Biology, 54: 82-105.

Baumgartner, G., K. Nakatani, L. C. Gomes, A. Bialetzki, P. V. Sanches \& M. C. Makrakis. 2008. Fish larvae from the upper Paraná River: do abiotic factors affect larval density? Neotropical Ichthyology, 6: 551-558.

Bedore, A. G. 1999. Características e criopreservação do sêmen de pacu-caranha (Piaractus mesopotamicus) e de piracanjuba (Brycon orbignyanus). Unpublished Ms. C. Dissertation, Universidade Federal de Minas Gerais, Belo Horizonte, MG, 53p.

Caneppele, D., R. M. Honji, A. W. S. Hilsdorf \& R. G. Moreira. 2009. Induced spawning of the endangered Neotropical species Steindachneridion parahybae (Siluriformes: Pimelodidae). Neotropical Ichthyology, 7: 759-762.

Cardoso, E. L., M. S. D. Alves, R. M. A. Ferreira \& H. P. Godinho. 1995. Embryogenesis of the neotropical freshwater Siluriformes Pseudoplatystoma coruscans. Aquatic Living Resources, 8: 343-346.

Carolsfeld, J., H. P. Godinho, E. Zaniboni Filho \& B. J. Harvey. 2003. Cryopreservation of sperm in Brazilian migratory fish conservation. Journal of Fish Biology, 63: 472-489.

Dabrowski, K., A. Murat \& J. Rinchard. 2008. Growth, maturation, induced spawning, and production of the first generation of South American catfish, Pseudoplatystoma sp., in North America. Journal of the World Aquaculture Society, 39: 174-183.

Drumond, M. M. 2008. Reprodução induzida de jaú (Zungaro jahu): análise das características seminais e ovocitárias. Unpublished Ms. C. Dissertation, Universidade Federal de Lavras, Lavras, MG, 108p.

Dumont-Neto, R., A. Pelli, J. L. Freitas, C. L. Costa, A. E. Freitas \& N. D. C. Barbosa. 1997. Reprodução induzida da piracanjuba (Brycon orbignyanus Valenciennes, 1903), cultivada em cativeiro na Estação de Pesquisa e Desenvolvimento Ambiental de Volta Grande-CEMIG. Boletim do Instituto de Pesca, 24: 105-107.

Essner, J. J., J. D. Amack, M. K. Nyholm, E. B. Harris \& H. J. Yost. 2005. Kupffer's vesicle is a ciliated organ of asymmetry in the zebrafish embryo that initiates left-right development of the brain, heart and gut. Development, 132: 1247-1260.

Gisbert, E. 1999. Early development and allometric growth patterns in Siberian sturgeon and their ecological significance. Journal of Fish Biology, 54: 852-862.

Gisbert, E., G. Merino, J. B. Muguet, D. Bush, R. H. Piedrahita \& D. E. Conklin. 2002. Morphological development and allometric growth patterns in hatchery-reared California halibut larvae. Journal of Fish Biology, 61: 1217-1229.

Godinho, A. L. 1998. Peixes. Pp. 479-481. In: A. B. M. Machado, G. A. B. Fonseca, R. B. Machado, L. M. S. Aguiar \& L. V. Lins (Eds.) Livro vermelho das espécies ameaçadas de extinção da fauna de Minas Gerais. Belo Horizonte, Fundação Biodiversitas, 605p.

Godinho, A. L., I. R. Lamas \& H. P. Godinho. 2010. Reproductive ecology of Brazilian freshwater fishes. Environmental Biology of Fishes, 87: 143-162.
Godinho, H. P. 2007. Estratégias reprodutivas de peixes aplicadas à aqüicultura: bases para o desenvolvimento de tecnologias de produção. Revista Brasileira de Reprodução Animal, 31: 351-360.

Hilsdorf, A. W. S., D. J. Penman, E. C. Farias \& B. McAndrew. 2002. Melanophore appearance in wild tilapia embryos. Pigment Cell Research, 15: 57-61.

Ihering, R. \& P. Azevedo. 1936a. As piabas dos açudes nordestinos (Characidae, Tetragonopterinae). Archivos do Instituto de Biologia, 7: 75-105.

Ihering R. \& P. Azevedo. 1936b. A desova e a hipofisação dos peixes: evolução de dois Nematognathas. Archivo Instituto Biológico 7: 107-118.

Instituto Mineiro de Gestão das Águas. 2008. Monitoramento da qualidade das águas superficiais da bacia do rio Grande. Available at: http://www.igam.mg.gov.br/

Kamler, E. 1992. Ontogeny of yolk-feeding fish: an ecological perspective. Reviews in Fish Biology and Fisheries, 12: 79-103.

Kendall Jr., A. W., E. H. Ahlstrom \& H. G. Moser. 1984. Early life history stages of fishes and their characters. American Society of Ichthyologists and Herpetologists, Special Publication, 1: 11-22.

Komen, H. \& G. H. Thorgaard. 2007. Androgenesis, gynogenesis and the production of clones in fishes: a review. Aquaculture, 269: 150-173.

Landines, M. A., J. A. Senhorini, A. I. Sanabria, \& E. C. Urbinati. 2003. Desenvolvimento embrionário do pintado (Pseudoplatystoma coruscans Agassiz, 1829). Boletim Técnico do CEPTA, 16: 1-13.

Legendre, M., O. Linhart \& R. Billard. 1996. Spawning and management of gametes, fertilized eggs and embryos in Siluroidei. Aquatic Living Resources, 9: 59-80.

Legendre, M., J. Slembrouck, J. Subagja, A. H. Kristanto. 2000. Ovulation rate, latency period and ova viability after $\mathrm{GnRH}$ - or hCG-induced breeding in the Asian catfish Pangasius hypophthalmus (Siluriformes, Pangasiidae). Aquatic Living Resources, 13:145-151.

Leonardo, A. F. G., E. Romagosa, M. I. Borella \& S. R. Batlouni. 2004. Induced spawning of hatchery-raised Brazilian catfish, cachara Pseudoplatystoma fasciatum (Linnaeus, 1766). Aquaculture, 240: 451-461.

Lundberg, J. G. \& M. W. Littmann. 2003. Family Pimelodidae (Longwhiskered catfishes). Pp. 432-446. In: R. E. Reis, S. O. Kullander $\&$ C. J. Ferraris, Jr. (Eds.). Checklist of the freshwater fishes of South and Central America. Porto Alegre, Edipucrs, 729p.

Luz, R. K., D. A. Reynalte-Tataje, A. A. Ferreira \& E. Zaniboni Filho. 2001. Desenvolvimento embrionário e estágios larvais do mandi-amarelo Pimelodus maculatus. Boletim do Instituto de Pesca, 27: 49-55.

Marques, C. 2008. Análise histológica e de microscopia eletrônica do desenvolvimento inicial de jaú (Zungaro jahu). Unpublished Ms. C. Dissertation, Universidade Estadual Paulista, Jaboticabal, SP, 84p.

Marques, C., L. S. O. Nakaghi, F. Faustino, L. N. Ganeco \& J. A. Senhorini. 2008. Observation of the embryonic development in Pseudoplatystoma coruscans (Siluriformes: Pimelodidae) under light and scanning electron microscopy. Zygote, 16: 333-342.

Mateus, L. A. F. \& J. M. F. Penha. 2007a. Dinâmica populacional de quatro espécies de grandes bagres na bacia do rio Cuiabá, Pantanal norte, Brasil (Siluriformes, Pimelodidae). Revista Brasileira de Zoologia, 24: 87-98.

Mateus, L. A. F. \& J. M. F. Penha. 2007b. Avaliação dos estoques pesqueiros de quatro espécies de grandes bagres (Siluriformes, Pimelodidae) na bacia do rio Cuiabá, Pantanal norte, Brasil, utili- 
zando alguns pontos de referência biológicos. Revista Brasileira Zoologia, 24: 144-150.

Matkovic, M. \& A. Pisanó. 1989. Estudio macro y microscopio del desarrollo de Hoplias m. malabaricus (Pisces, Erythrinidae). I: fase larval. Revista Brasileira de Biología, 49: 553-569.

Meijide, F. J. \& G. A. Guerrero. 2000. Embryonic and larval development of a substrate-brooding cichlid Cichlasoma dimerus (Heckel, 1940) under laboratory conditions. Journal of Zoology, 252: 481-493.

Mikich, S. B. \& R. S. Bérnils. 2004. Livro vermelho da fauna ameaçada no Estado do Paraná. Curitiba, Instituto Ambiental do Paraná, 764p.

Nakatani, K., A. A. Agostinho, G. Baumgartner, A. Bialestzki, P. V. Sanches, M. C. Makrakis \& C. S. Pavanelli. 2001. Ovos e larvas de peixes de água doce. Maringá, Eduem, 378p.

Ninhaus-Silveira, A., F. Foresti \& A. Azevedo. 2006. Structural and ultrastructural analysis of embryonic development of Prochilodus lineatus (Valenciennes, 1836) (Characiformes; Prochilodontidae). Zygote, 14: 217-229.

Nuñez, J., R. Dugué, N. C. Arana, F. Duponchelle, J. F. Renno, T. Raynaud, N. Hubert \& M. Legendre. 2008. Induced breeding and larval rearing of Surubí, Pseudoplatystoma fasciatum (Linnaeus, 1766), from the Bolivian Amazon. Aquaculture Research, 39: 764-776.

Padilha Peréz, P., F. A. Bocanegra \& R. I. Orbe. 1991. Reproducción inducida de la doncella Pseudoplatystoma fasciatum y desarrollo embrionario-larval. Folia Amazónica, 12: 141-154.

Perini, V. R., Y. Sato, E. Rizzo \& N. Bazzoli. 2009. Biology of eggs, embryos and larvae of Rhinelepis aspera (Spix \& Agassiz, 1829) (Pisces: Siluriformes). Zygote, 18: 159-171.

Phelps, R. P., R. Hastey, A. Pendetar, L. Linley, N. Papanikos \& R. A. Dunham. 2007. Effects of temperature on the induced spawning of channel catfish and the production of channel $\times$ blue catfish hybrid fry. Aquaculture, 273: 80-86.

Psenicka, M., M. Rodina \& O. Linhart. 2010. Ultrastructural study on the fertilisation process in sturgeon (Acipenser), function of acrosome and prevention of polyspermy. Animal Reproduction Science, 117: 147-154.

Quirós, R. 1993. Inland fisheries under constraints by other uses of land and water resources in Argentina. In: Prevention of water pollution by agriculture and related activities. FAO Water Reports, 1: 29-44.

Resende, E. K. 2003. Migratory fishes of the Paraguay-Paraná River Basin, excluding the Upper Paraná Basin. Pp. 99-155. In: J. Carolsfeld, B. Harvey, C. Ross \& A. Baer (Eds.). Migratory fishes of South America: biology, fisheries and conservation status. Victoria, World Fisheries Trust, the World Bank and the International Development Research Centre, 372p.

Ribeiro, R. I. M. A. \& H. P. Godinho. 2003. Criopreservação do sêmen testicular do teleósteo piau-açu Leporinus macrocephalus. Arquivo Brasileiro de Medicina Veterinária e Zootecnia, 55: 75-79.

Riehl, R. \& R. A. Patzner. 1998. Minireview: The modes of egg attachment in teleost fishes. Italian Journal of Zoology, 65: 415-420.

Rizzo, E., Y. Sato, B. P. Barreto \& H. P. Godinho. 2002. Adhesiveness and surface patterns of eggs in Neotropical freshwater teleosts. Journal of Fish Biology, 61: 615-632.

Rodrigues-Galdino, A. M., C. V. Maiolino, M. Forgati, L. Donatti, J. D. Mikos, P. C. F. Carneiro \& F. S. A. Rios. 2009. Development of the neotropical catfish Rhamdia quelen (Siluriformes, Heptapteridae) incubated in different temperature regimes. Zygote, 18: 131-144.
Romagosa, E., S. R. Batlouni, M. I. Borella \& A. F. G. Leonardo. 2005. Involução dos folículos pós-ovulatórios em Pseudoplatystoma fasciatum (Pisces, Teleostei). Boletim do Instituto de Pesca, 31: 129-135.

Santos, J. E. \& H. P. Godinho. 2002. Ontogenetic events and swimming behavior of the larvae of the characid fish Salminus brasiliensis (Cuvier, 1817). Revista Brasileira de Zoologia, 19: 163-171.

Sato, Y. 1999. Reprodução de peixes da bacia do rio São Francisco: indução e caracterização de padrões. Unpublished Ph.D. Dissertation, Universidade Federal de São Carlos, São Carlos, SP, 179p.

Sato, Y., E. L. Cardoso, W. B. Sallum \& H. P. Godinho. 1997. Indução experimental da desova do surubim Pseudoplatystoma coruscans. Pp. 69-79. In: M. O. T. Miranda (Org.). Surubim. Belo Horizonte, IBAMA, 157p.

Sato, Y., N. Fenerich-Verani, H. P. Godinho, E. V. Sampaio. 1999. Reproductive traits of the yellow-mandi catfish Pimelodus maculatus Lacépéde (Osteichthyes, Siluriformes) in captive breeding. Revista Brasileira de Zoologia, 16: 981-986.

Sato, Y., N. Fenerich-Verani, A. P. O. Nuñer, H. P. Godinho \& J. R. Verani. 2003a. Padrões reprodutivos de peixes da bacia do São Francisco. Pp. 229-274. In: H. P. Godinho \& A. L. Godinho (Orgs.). Águas, peixes e pescadores do São Francisco das Minas Gerais. (Eds.). Belo Horizonte, PUC Minas, 458p.

Sato, Y., N. Fenerich-Verani \& H. P. Godinho. 2003b. Reprodução induzida de peixes da bacia do São Francisco. Pp. 275-289. In: H. P. Godinho \& A. L. Godinho (Orgs.). Águas, peixes e pescadores do São Francisco das Minas Gerais. Belo Horizonte, PUC Minas, 458p.

Sato, Y., N. Fenerich-Verani, J. R. Verani, H. P. Godinho \& E. V. Sampaio. 1998. Induced reproduction and reproductive characteristics of Rhinelepis aspera Agassiz, 1829 (Osteichthyes: Siluriformes, Loricariidae). Brazilian Archives of Biology and Technology, 41: 309-314.

van Snik, G. M. J., J. G. M. van den Boogaart \& J. W. M. Osse. 1997. Larval growth patterns in Cyprinus carpio and Clarias gariepinus with attention to the finfold. Journal of Fish Biology, 50: 1339-1352.

Viveiros, A. T. M. \& H. P. Godinho. 2009. Sperm quality and cryopreservation of Brazilian freshwater fish species: a review. Fish Physiology and Biochemistry, 35: 137-150.

Winemiller, K. O. 1989. Patterns of variation in life history among South American fishes in seasonal environments. Oecologia, 81: 225-241.

Woynarovich, E. \& L. Horváth. 1980. The artificial propagation of warm-water finfishes - a manual for extension. FAO Fisheries Technical Paper, 201: 1-183.

Zaniboni Filho, E. \& N. D. C. Barbosa. 1996. Priming hormone administration to induce spawning of some Brazilian migratory fish. Revista Brasileira de Biologia, 56: 655-659.

Zaniboni Filho, E. \& U. H. Schulz. 2003. Migratory fishes of the Uruguay River. Pp. 157-194. In: J. Carolsfeld, B. Harvey, C. Ross \& A. Baer (Eds.). Migratory fishes of South America: biology, fisheries and conservation status. Victoria, World Fisheries Trust, the World Bank and the International Development Research Centre, 372p.

Submitted February 17, 2011

Accepted September 16, 2011

Published March 30, 2012 